\title{
The Concept of Waste within the Framework of Sustainable Development through the Analysis of the Secondary Education Curriculum
}

\author{
Guadalupe Martínez Borreguero ${ }^{1 *}$, Jesús Maestre Jiménez ${ }^{1}$, Francisco Luis Naranjo Correa ${ }^{1}$ \\ ${ }^{1}$ Department of Didactics of Experimental Sciences, University of Extremadura, Avda. De Elvas, Badajoz, SPAIN
}

Received 22 May 2017 - Revised 24 August 2017 • Accepted 6 October 2017

\begin{abstract}
The overall purpose was to analyze the reference to the concept of waste (closely related to sustainable development within the framework of environmental education) in the regulation that standardizes Compulsory Secondary Education. A qualitative research design was carried out based on a descriptive statistical analysis. A system of categories has been established. The different subjects in which the concept of waste is taught, the contents proposed and the approach that is given to the concept were analyzed. The concept of waste appeared in different expressions, which were the indicators of this study. The results reveal that the current legislation, both national and regional, gives very little relevance to this concept. Although the regulations offer opportunities in education to study this concept, it is insufficient and incomplete in this regard. These results allow us to affirm that the study of the concept of waste in the school stage is not encouraged.
\end{abstract}

Keywords: curriculum, science education, scientific literacy, sustainable development, teaching, waste

\section{INTRODUCTION}

In today's society, a scientific and technologically developed society, the right management and treatment of waste is vital to alleviate the environmental problems involved, minimize environmental impact and achieve sustainable development. Waste is, however, usually perceived as just garbage, and the educational field can be a major instrument to change this view and recognize waste as, for example, a resource that can be reused again. We consider it necessary to train society from the school stage and carry out an analysis of how the concept of waste is treated in the current educational system.

A significant amount of waste is generated every day, associated with both daily and economic activities. The Organization for Economic Co-operation and Development (OECD) indicates in its Environmental Outlook to 2030 (OECD, 2008) that in the field of waste there are environmental problems which are not being carried out under proper management and can lead to serious problems in the environment. This includes, for example, problems related to the management of waste itself, transport of hazardous waste and waste from developing countries, among others. In addition, in this report, reference is made to a number of wastes that cause environmental problems but their management is improving, among which can highlight urban waste and Chlorofluorocarbons (CFCs) emissions. The correct management and treatment of waste is of vital importance to lessen the environmental problems they entail, with the aim of minimizing the environmental impact and achieving sustainable development. However, it is necessary to change the view of waste as trash and perceive it as, for example, a resource that can be reused again. For this change, the educational field can be a major instrument. For this reason, we consider it necessary to educate society from the school stage and carry out an analysis of the treatment of the concept of waste in the current educational system. 


\section{Contribution of this paper to the literature}

- There is a lack of studies on the analysis of the concept of waste in the curriculum. The present research focused on this concept within the framework of sustainable development based on the analysis of the curriculum of secondary education.

- This work establishes a system of categories that serve as a basis for the implementation of didactic interventions on waste in students of different educational levels.

- It is necessary to have a correct cognitive domain of the concept to be able to foster responsible attitudes in the current and future generations that allow a sustainable development in all sectors involved.

To understand the meaning of the concept of waste, one can start from the etymological sense of the noun. It comes from Latin vastus, with a sense of "unfit for use," "consumption, depletion," and also "useless expenditure" (c. 1300). The meaning of "refuse matter" is attested from c. 1400. In Spanish, the word "residuo" is preferably used. Like its English counterpart residue, it comes from the Latin residuum and defines the elements that lose a utility once they have fulfilled a function to perform a certain work. If we extend the definition according to the different fields of application of the concept (educational, social or environmental), the word residue has different meanings. Thus, from synonymy, we can find the words debris, detritus, remains, rubbish, garbage, trash or litter, the latter four being the most used in everyday language.

To make a comparative of the information on solid waste generated in the world, the OECD recommends a detailed classification of the origin of the waste. For example, the first report on solid waste management in Chile refers to two forms of waste treatment: disposal and recovery. The first refers to "any action associated with the final treatment whose purpose is to treat or dispose of waste without taking advantage of their materials or energy value." The second indicates "a set of associated actions whose objective is to recover a product, one or several of the materials that compose it or their calorific value" (CONAMA, 2010).

Taking into account the above, from the point of view of environmental education, the concept of waste is related to the concept of sustainable development because of the environmental implications of its treatment and proper management. Several scientific studies have been carried out on the term of sustainable development (Barbier, 1987; Harborth, 1991; Lelé, 1991; Pezzoli, 1997). One of the foundations of this concept dates back to 1987 with the "Brundtland Report" in which the World Commission on Environment and Development (WCED) states that "sustainable development is development that meets the needs of the present without compromising the ability of future generations to meet their own needs" (WCED, 1987, p. 43). Foladori, \& Tommasino (2000) perform a bibliographic analysis on the evolution of the concept of sustainable development during the last thirty years. Other authors (Middleton, \& O'Keefe, 2001) redefine the concept of sustainable development. Beatley \& Manning (1998) believe that sustainable development must be promoted and planned. Thus, environmental problems related to greenhouse gas emissions and loss of biodiversity have urged the implementation of sustainable actions on land use (Vitousek et al., 1997). More recently, Berke \& Conroy (2000) ask in their research: “Are We Planning for Sustainable Development? Specifically, they analyze a series of principles with the objective of checking if they define and operationalize the concept of sustainable development, evaluating different plans and their policies to support sustainable development.

Specifically, there has been an effort over the last thirty years on the pair development-environment and how environmental education has influenced and influences different approaches that allow a true evolution that respects environmental limits and promulgates equity and sustainability (Novo, 2009). Authors such as Scott (2005) consider that education is a critical tool for moving towards sustainability. This author emphasizes as well that education for sustainable development can be regarded as an opportunity to address future social and environmental challenges from politics. Other research (Firth and Winter, 2007) is based on a study with teachers in training analyzing the formation of a sample of geography teachers as well as the educational system as a means to build education for sustainable development. Other papers study more specifically sustainable development in the context of education in recent years and relate the education for sustainable development with the curriculum. For example, Summers and Kruger (2003) illustrate how a group a primary school teachers transferred a theoretical view of education for sustainable development into student learning. Grace and Sharp (2000) carried out a study in which they analyzed the opinions of teachers in training on various aspects of environmental education. Among its results, it is worth noting that, despite the absence of a school specific policy on environmental education, teachers presented a positive attitude towards this issue and it was usually addressed in class. Williams, McEwen, \& Quinn (2016) study aspects related to climate change through a participatory methodology with children from seven to nine years. Their results reveal that intergenerational learning from child to parent is possible and that children transfer ideas from school to home. Tugurian \& Carrier (2017) study the relationship between the natural world and environmental identity in a qualitative way through interviews with 17 fifth graders. The results show that children recognize their environmental identity, but it is often unacknowledged in the science classroom. A 
study by Kinbert (2000) analyzes attitudes, behaviors, and knowledge related to the environment at college. The results show a poor environmental culture in the selected sample of 817 university students. Gomera-Martinez (2008) concludes that environmental awareness (with its four dimensions, cognitive, affective, conative and active) is a tool for environmental education at university level. Bray (2008) poses the following question: "Do educational programs use environmentally, socially and economically sustainable teaching methods?" Specifically, the author points out that some universities have begun to develop programs to evaluate the sustainability of teaching methods to ensure that economic, social and environmental resources are not overused. Other authors (Aznar, Martínez-Agut, Palacios, Piñero \& Ull, 2011) conducted a study with teachers with the purpose of introducing the concept of Sustainability in higher education. These authors claim to understand the concept of sustainability from a holistic perspective, so that not only the concept but also the process and strategy are involved (Adomssent, Godemann \& Michelsen, 2007). In line with the previous approach, some authors (Vega Marcote et al., 2007) point out that it is necessary to build a social model making possible a sustainable and efficient model, highlighting education as one of the tools to achieve this. Specifically, the society of developed countries is linked to a series of environmental problems, among which is the generation of waste, which, without proper management and treatment, can put the health of the Earth at risk.

Given this, the challenge of proper waste management at all levels is that individuals with education, as well as institutions with legislation, act to improve the present and take care of the future. To this end, although there are numerous directives from the European Union, the first waste normative to come into force in Spain was Law 10/1998 "Waste Act." The normative, an adaptation of Council Directive 91/156/EEC, has been repealed by Law 22/2011, which is currently in force.

The United Nations General Assembly promoted Education for Sustainable Development by resolution 57/254 of 20 December 2002, which indicated that education is a fundamental tool for achieving the goals of sustainable development. It also promotes Education for Sustainable Development to provide everyone with the opportunity to acquire values, competences, knowledge and skills that enable them to contribute to a just, economically viable and ecologically sustainable human future (UNESCO, 2005; Tilbury, 2011).

An approach focused on the education of individuals must take into account the basic demands of the Spanish educational system. These demands have an important role in achieving the objectives towards environmental sustainability, such as the right management of waste. However, in educational terms, there are no similar studies on the concept of waste as discussed in the previous paragraphs. For this reason, the present research focused on the concept of waste within the framework of sustainable development for today's society based on the analysis of the curriculum of secondary education.

Our work follows a structure similar to that of other authors (Jóhannesson et al., 2011) but applied to the concept of waste as the object of study. Specifically, the research by Jóhannesson et al. (2011) examines education for sustainable development in the Icelandic public school curriculum for early childhood, compulsory and upper secondary education from a holistic point of view. Likewise, Sureda-Negre, Catalán-Fernández, Álvarez-García, \& Comas-Forgas, (2013) worked with the concept of sustainable development in Compulsory Secondary Education, in Spain analyzing the Royal Decree 1631/2006 that Regulates the curriculum nationwide and locally in the Autonomous Communities of Madrid and the Balearic Islands through Decrees 23/2007 and 73/2008 respectively. In this work, the methodological guidelines of the authors mentioned above are followed, but in the field of waste. We consider that it is relevant for the current society to consider waste within our educational system. It is necessary to have a correct cognitive domain of the concept to be able to foster responsible attitudes in the current and future generations that allow a sustainable development in all sectors involved (economic, social or environmental).

\section{METHODOLOGY OF RESEARCH}

\section{Problem of Research and Objectives}

The problem is focused on determining the role played by the concept of waste from sustainable development in state and regional regulations. The general objective of the study was to analyze the reference to the concept of waste in the regulation that standardizes Compulsory Secondary Education (CSE) and Baccalaureate in Spain, both nationwide through Royal Decree 1105/2014 and at the regional level of the Autonomous Community of Extremadura through Decree 98/2016. In Spain, CSE is organized into four school years which are ordinarily coursed between the ages of 12 and 16, and Baccalaureate consists in two school years of non-compulsory education, ordinarily coursed between the ages of 17 and 18 . 
The general objective has been broken down into the following specific objectives:

Specific Objective 1 (SO1): To analyze from a lexicographic perspective the word waste in the decrees cited above.

Specific Objective 2 (SO2): To analyze the subjects in which the concept of waste appears in the curriculum of CSE and Baccalaureate.

Specific Objective 3 (SO3): To establish a system of categories that allow studying the approach of the concept of waste in the regulation that standardizes the curriculum of CSE and Baccalaureate.

Specific Objective 4 (SO4): To analyze what elements should be added to the current curriculum to complete school education about the concept of waste.

The research questions that have guided the development of this work, based on the ones made by other researchers in similar topics (Sureda-Negre et al., 2013), are directly related to the specific objectives previously indicated. They were the following:

Research Question 1 (RQ1): What concepts directly related to waste appear in the decrees that regulate the curriculum of CSE and Baccalaureate? How often do they appear? What importance is given to these concepts?

Research Question 2 (RQ2): What contents are proposed in the different subjects of the CSE and Baccalaureate curricula?

Research Question 3 (RQ3): What approach to waste is adopted in the decrees? Is the same approach proposed in all subjects?

Research Question 4 (RQ4): What important current elements should be added to the curriculum to complete waste training in the different disciplines involved?

\section{Instrument and Procedures}

The procedure for the achievement of the stated objectives that allow answering the different research questions was to analyze the references to the concept of waste in the regulation that standardizes secondary education in Spain, both nationwide through Royal Decree 1105/2014 and at the regional level of the Autonomous Community of Extremadura through Decree 98/2016. For that, the contents proposed and the approach that is given to the concept of waste were analyzed in the different subjects in which the concept is taught. A qualitative research design was carried out based on a descriptive statistical analysis. The word waste and all the related statements were analyzed in the legal texts cited above, in order to establish a structure of categories. Apart from the term of waste, which is literally stated in the regulations, social, economic and environmental factors have been taken into account. The established categories were Waste \& Society, Awareness \& Ethics, Technological Development, Regulations \& Economy, and Typology. The results show that the concept of waste appeared in different expressions, which were the indicators of this study.

\section{Data Analysis}

The research design is focused on finding content related to the concept of waste, either through the word itself or statements that refer to the concept of waste from sustainable development. The search was made using a word search engine in Royal Decree 1105/2014 which regulates CSE in Spain. With the purpose of making a comparison for further studies, the same procedure was performed in Decree 98/2016 which regulates the same secondary education in the Autonomous Community of Extremadura. From the study of all the elements related to the concept analyzed in the current regulations, five categories were established, which were used to group the concepts and thus be able to carry out the research.

\section{RESULTS}

The results obtained regarding the Specific Objective 1 (SO1) proposed in this research will be shown first. The lexicographic analysis indicates that the word waste appears in six different forms or expressions in the Royal Decree that standardizes the curriculum of CSE and Baccalaureate in Spain. These various expressions are used as the indicators of the study, which are: I1 - Waste; I2 - Waste Treatment; I3 - Waste Management; I4 - Social Impact of Waste; I5 - Waste Disposal; I6 - Sources of Waste. Table 1 shows the total number of references according to the different indicators in the decrees studied.

As can be seen in Table 1, these concepts appear on 18 occasions in the case of Royal Decree 1105/2014, and 25 in Decree 98/2016. The percentages are similar comparing national and regional regulations. On the total of 
Table 1. Number of times ( $n$ ) and percentage the reference to waste appears in the different indicators in the specified regulation

\begin{tabular}{|c|c|c|c|c|c|c|c|}
\hline & $\begin{array}{c}\text { (I1) } \\
\text { Waste } \\
\text { n } \\
(\%)\end{array}$ & $\begin{array}{c}\mathbf{( 1 2 )} \\
\text { Waste Treatment } \\
\mathrm{n} \\
(\%)\end{array}$ & $\begin{array}{c}\text { (I3) } \\
\text { Waste } \\
\text { Management } \\
\mathrm{n} \\
(\%) \\
\end{array}$ & $\begin{array}{c}\mathbf{( 1 4 )} \\
\text { Social Impact of } \\
\text { Waste } \\
n \\
(\%) \\
\end{array}$ & $\begin{array}{c}\text { (I5) } \\
\text { Waste } \\
\text { Disposal } \\
\mathrm{n} \\
(\%) \\
\end{array}$ & $\begin{array}{c}\mathbf{( I 6 )} \\
\text { Sources of } \\
\text { Waste } \\
n \\
(\%) \\
\end{array}$ & $\begin{array}{l}\text { Total } \\
\mathrm{N}\end{array}$ \\
\hline $\begin{array}{c}\text { Royal Decree } \\
1105 / 2014 \\
\end{array}$ & $\begin{array}{c}1 \\
(5.6 \%) \\
\end{array}$ & $\begin{array}{c}7 \\
(38.9 \%) \\
\end{array}$ & $\begin{array}{c}3 \\
(16.7 \%) \\
\end{array}$ & $\begin{array}{c}2 \\
(11.1 \%) \\
\end{array}$ & $\begin{array}{c}2 \\
(11.1 \%) \\
\end{array}$ & $\begin{array}{c}3 \\
(16,7 \%) \\
\end{array}$ & 18 \\
\hline $\begin{array}{c}\text { Decree } \\
98 / 2016 \\
\end{array}$ & $\begin{array}{c}3 \\
(12.0 \%) \\
\end{array}$ & $\begin{array}{c}9 \\
(36.0 \%) \\
\end{array}$ & $\begin{array}{c}5 \\
(20.0 \%) \\
\end{array}$ & $\begin{array}{c}2 \\
(8.0 \%) \\
\end{array}$ & $\begin{array}{c}3 \\
(12.0 \%) \\
\end{array}$ & $\begin{array}{c}3 \\
(12.0 \%) \\
\end{array}$ & 25 \\
\hline Total & $\begin{array}{c}4 \\
(9.1 \%)\end{array}$ & $\begin{array}{c}16 \\
(36.4 \%)\end{array}$ & $\begin{array}{c}8 \\
(18.2 \%)\end{array}$ & $\begin{array}{c}5 \\
(11.4 \%)\end{array}$ & $\begin{array}{c}5 \\
(11.4 \%)\end{array}$ & $\begin{array}{c}6 \\
(13.6 \%)\end{array}$ & 44 \\
\hline
\end{tabular}

Table 2. Number of references to the concept of waste (and percentage) in the various subjects of the curriculum of CSE and Baccalaureate

\begin{tabular}{|c|c|c|c|c|c|c|c|c|c|c|c|c|c|c|}
\hline \multirow{3}{*}{$\begin{array}{l}\text { EDUCATIONAL } \\
\text { LEVEL }\end{array}$} & \multirow{3}{*}{ SUBJECT } & \multirow{3}{*}{ YEAR } & \multicolumn{5}{|c|}{ ROYAL DECREE } & \multicolumn{5}{|c|}{ DECREE } & \multirow{2}{*}{\multicolumn{2}{|c|}{$\begin{array}{c}\text { TOTAL } \\
\text { REFERENCES }\end{array}$}} \\
\hline & & & & 11 & $05 / 2$ & 2014 & & & & $8 / 2$ & 2016 & & & \\
\hline & & & $\mathrm{CO}$ & $\mathrm{EC}$ & LS & IS & $\%$ & $\mathrm{CO}$ & EC L & LS & IS & $\%$ & $\mathrm{~N}$ & $\%$ \\
\hline \multirow{7}{*}{ CSE } & $\begin{array}{l}\text { Scientific } \\
\text { Culture }\end{array}$ & $4^{\text {th }}$ & & 1 & 1 & & 11.8 & & 1 & 1 & & 11.1 & 4 & 11.4 \\
\hline & $\begin{array}{c}\text { Biology \& } \\
\text { Geology }\end{array}$ & $4^{\text {th }}$ & 1 & 2 & 1 & & 23.5 & 1 & 2 & 1 & & 22.2 & 8 & 22.9 \\
\hline & $\begin{array}{c}\text { Sciences Applied to Professional } \\
\text { Activity }\end{array}$ & $4^{\text {th }}$ & 1 & 3 & 2 & 1 & 41.2 & 1 & 3 & 2 & 1 & 38.9 & 14 & 40.0 \\
\hline & Technology & $3^{\text {rd }}$ & & & & & 0.0 & 1 & & & 1 & 11.1 & 2 & 5.7 \\
\hline & \multirow{2}{*}{ Physics \& Chemistry } & $2^{\text {nd }}$ & & 1 & 1 & & 11.8 & & 1 & & & 5.6 & 3 & 8.6 \\
\hline & & $3^{\text {rd }}$ & & 1 & 1 & & 11.8 & & 1 & 1 & & 11.1 & 4 & 11.4 \\
\hline & Total CSE & & 2 & 8 & 6 & 1 & 100.0 & 3 & 8 & 5 & 2 & 100.0 & 35 & 100.0 \\
\hline \multirow{5}{*}{ BACCALAUREATE } & Earth \& Environmental Sciences & $2^{\text {nd }}$ & & 1 & 1 & & 66.7 & 2 & 1 & 15 & 57.1 & & 6 & 60.0 \\
\hline & Economics & $1^{\text {st }}$ & & & 1 & & 33.3 & & & 1 & 14.3 & & 2 & 20.0 \\
\hline & $\begin{array}{c}\text { Industrial } \\
\text { Technology I }\end{array}$ & $1^{\text {st }}$ & & & & & 0.0 & 1 & & & 14.3 & & 1 & 10.0 \\
\hline & $\begin{array}{c}\text { Industrial } \\
\text { Technology II }\end{array}$ & $2^{\text {nd }}$ & & & & & 0.0 & 1 & & & 14.3 & & 1 & 10.0 \\
\hline & Total Baccalaureate & & 0 & 1 & 2 & 0 & 100.0 & 4 & 1 & 2 & 0 & 100.0 & 10 & 100.0 \\
\hline
\end{tabular}

indicators evaluated, the most representative is I2 (Waste Treatment), with a percentage of $36.4 \%$. I3 (Waste Management) represents $18.2 \%$ of all references. The rest have very similar percentages, the highest being I6 (Waste Sources) with $13.6 \%$, and the lowest, with $9.1 \%$, is I1 (Waste).

The results obtained regarding the Specific Objective 2 (SO2) proposed in this research are shown in Table 2, which lists the references related to the concept of waste, as well as the subjects in which it is taught, the school year and in which category it is found. The categories are regulated in the decrees studied, and are as follows: Contents (CO), Evaluation Criteria (EC), Learning Standards (LS) and Introduction of the Subject (IS).

It can be seen in Table 2 that the greatest number of references in CSE focus on the subject of Sciences Applied to Professional Activity, followed by Biology $\mathcal{E}$ Geology. Both subjects are in the $4^{\text {th }}$ year of CSE, but none of them is a core subject. Similarly, it can be observed that the subject that stands out in Baccalaureate is Earth $\mathcal{E}$ Environmental Sciences. Considering jointly the two legal provisions, the greatest number of references appears in the subject of Sciences Applied to Professional Activity, followed by Biology \& Geology. With a slightly smaller number of references we have Physics $\mathcal{E}$ Chemistry and Earth $\mathcal{E}$ Environmental Sciences. It can be observed that the three subjects with more references to the field of waste are on CSE. As for the Technology subjects, they only present references in the regional regulation. The percentages in the different subjects of CSE are very similar in both regulations; there is a moderate difference in the Technology subject, where the percentage of the references in the regional normative is higher than in the national regulation. On the other hand, there are three of the four subjects with very different percentages in Baccalaureate, being Earth \& Environmental Sciences the most prominent. Also noteworthy is the fact that there is no reference to the concept of waste in the subjects of Industrial Technology I and Industrial Technology II in the national normative.

According to the analysis of the educational offer that appears in the regulations, the student takes the core subjects of Physics and Chemistry in the $2^{\text {nd }}$ and $3^{\text {rd }}$ year of CSE. In the $3^{\text {rd }}$ year, and only if the center offers it, the 
student can opt to take the Technology subject, where he can complement his training in waste. In the $4^{\text {th }}$ year, the student can choose to study some of the optional subjects that teach concepts related to waste, Scientific Culture and Sciences Applied to Professional Activity. In Baccalaureate, the student can only receive training in the concept of waste if the center offers some optional subjects. Since the concept is not taught in any core subject, the student must also decide to take these specific subjects. In the $1^{\text {st }}$ year, the concept is taught in the subjects of Economics and Industrial Technology I, while in the $2^{\text {nd }}$ year the students can take the specific subjects of Industrial Technology II and Earth $\mathcal{E}$ Environmental Sciences.

The results obtained regarding the Specific Objective 3 (SO3) proposed in this research are shown below. A system of categories has been established based on previous studies (Maestre, Martinez \& Naranjo, 2017) to obtain the approach provided by both national and regional regulations to higher education students and teachers in their classroom. The categories established for the subject under study have been the following (a specific example of each category is shown in parentheses):

- Category I - Waste \& Society (WS): In this category, we include references to environmental or social problems in which waste is referenced (CSE extract: "Specify what nuclear pollution is, reflect on nuclear waste management").

- Category II - Awareness \& Ethics (AE): It references to the importance of the perspective of ethics and awareness in the problem of waste (CSE extract: "Assesses and describes the impacts of overexploitation of natural resources, pollution, desertification, waste treatment and proposes personal and collective solutions and attitudes to mitigate them").

- Category III - Technological Development (TD): It includes references to the contribution of technological development to the correct solution of challenges related to waste (CSE extract: "Specify the procedural stages involved in waste treatment").

- Category IV - Regulations \& Economy (RE): There are those references related to waste regulations and those that affect economic activities (Baccalaureate extract: "Identifies environmental goods as a scarce production factor, which provides inputs and collects waste and residues, which means assessing the associated costs").

- Category V - Typology (TY): References related to the typology and origin of the waste (CSE extract: "Students learn about the different types of environmental pollutants, their sources and negative effects, as well as the treatment to reduce their effects and eliminate the generated waste").

The impact that the concept of waste has on the curriculum can be analyzed with these categories, since any element related to the concept under study can be detected. The references that appear in the texts are now analyzed according to the category studied. Specifically, Category III (Technological Development) presents the largest number. The rest of categories are quite similar, except for Category IV (Normative \& Economy), which has no reference in this field. Similarly, in Baccalaureate, there are only three references in all existing categories, being two on Category V (Typology) and one in Category IV (Normative \& Economy). From the analysis of all sentences, it can be concluded that the training in waste during Baccalaureate is less important and much poorer than during CSE, as most of the references appear in the CSE stage. The results obtained from the different categories are detailed below.

\section{Category I: Waste \& Society (WS)}

There are three references to the social link to waste, which are located in CSE. Two emphasize the importance of nuclear waste management (one of them addresses waste management from the social point of view, and treatment in the other).

\section{Category II: Awareness \& Ethics (AE)}

They appear three references where it can be appreciated the awareness and the ethical part that society must present with respect to waste, all of them are in CSE subjects. Two of the references deal with selective waste collection and how it affects at social and domestic level; Another reference proposes solutions and attitudes, both collective and individual, to reduce or mitigate waste.

\section{Category III: Technological Development (TD)}

There are five references that deal with the technological development related to waste, all linked to CSE. Four of the references talk about the technological development on the treatment of waste. One of them refers to the different techniques to assess the degree of pollution of the environment.

\section{Category IV: Regulations \& Economy (RE)}

A reference to the relationship between economic activity and waste appears. This reference is in a Baccalaureate subject. 


\section{Category V: Typology (TY)}

Five references appear that address the type of waste to be studied and how to take the appropriate measures for its reduction or elimination. Two of the references deal with the origin of waste (in Baccalaureate subjects), while the remaining three (in CSE subjects) refer to the type of waste as well as its identification in order to be able to treat it correctly.

It can be observed that the concept of waste is hardly mentioned in the curricula. In CSE subjects, Technological Development is the category with the greatest impact in the curriculum, while the categories of Waste \& Society, Awareness \& Ethics, and Regulations and Economy present a number of very similar statements. In the two school years of non-compulsory training, the number of statements that appear in the subjects is minimal, being most of them in the category of Typology.

\section{DISCUSSION}

In the first place, it should be pointed out that the legislation studied, both national and regional, does not give much importance to the concept of waste. Six subjects in the national regulation deal with waste in the different fields studied, and nine in the regional decree. Although they seem many subjects, the concept is given little relevance in each one of them. Besides, of the two compulsory subjects in which the concept is studied during the first three years of CSE (Physics \& Chemistry and Biology \& Geology), in one itinerary (see Table 2) the concept is seen only in the $2^{\text {nd }}$ and $3^{\text {rd }}$ year within the subject of Physics \& Chemistry. The concept of waste is not studied in any core subject of the $4^{\text {th }}$ year.

Both the regional and national regulations offer opportunities in education to study this concept. However, the real possibilities depend more on the educational offer of the administration and the centers, as well as the competence and willingness of teachers to explain this concept within the normative framework. Otherwise, the system is insufficient and incomplete in this aspect.

It should also be noted that, during the non-compulsory stage of training (specifically in the $1^{\text {st }}$ year of Baccalaureate), the concept of waste could be taught in the subject of Biology \& Geology in the itinerary of Sciences (depending on the educational offer and the student's choice). However, in the itinerary of Social Sciences and Humanities, the concept is only seen on the subject of Economics, depending in addition to the educational offer of the center. There is also the possibility to study the concept of waste in the itinerary of Art.

In the case of the specific subjects to be selected by the student, the concept of waste can be studied in the subjects of Scientific Culture and Industrial Technology I. In the 2nd year of Baccalaureate there is no option to study the concept in the core subjects, independently of the itinerary. The concept could only be imparted in the subjects offered by the center (if offered at all), such as Earth \& Environmental Sciences and Industrial Technology II.

All this legislative system that regulates the subjects in which this concept of waste is imparted prevents its correct learning, which generates negative results both in teaching and in the understanding of the concept.

\section{CONCLUSIONS AND IMPLICATIONS}

Based on the results obtained, we consider that the regulations governing secondary education in Spain must deal more deeply with the concept of waste from a holistic point of view. This is currently an element of vital importance in the sustainable development and formation of the citizenship, mainly from the social and environmental perspective.

The limited role played by the concept of waste in legislation is transferred to our society, materializing in the lack of proper management and causing environmental problems. Analysis and studies from different fields show that the contemporary capitalism instigates cultural and ecological challenges. Our society needs education and technology to remedy and palliate financial and economic crises, poverty, inequality, environmental changes, and so forth (Pavlova, 2013).

It would be interesting to include in the Spanish educational system the concept of clean point, which must be installed in municipalities with more than 5,000 inhabitants by 2010 and all municipalities with more than 2,000 inhabitants before 2015, according to the resolution of January 20, 2009, of the Secretary of State for Climate Change, which makes know the Agreement of the Council of Ministers approving the Integrated National Waste Plan. The concept of clean point may help to contribute to the correct elimination of household waste that cannot be deposited in other containers. Using the clean points dangerous waste of domestic origin, that outside by this type of installations could cause serious damages to the environment (such as refrigerators, luminaries, and so forth), are collected. In this way, this waste can be treated correctly, thus preserving both the health of citizens and the environment. Another measure to adopt in this area could be the control of the uncontrolled dumping of this type 
of waste since many of them are left in illegal landfills preventing their correct treatment and generating environmental problems in the area where they are deposited.

Also, within the framework of education for sustainable development, it would seem right to include a new block of "environmental pollution generated by waste" in the core subject of Biology \& Geology taught in the first and third years of CSE, to train the student in the field of awareness and responsibility towards waste.

However, all these measures should start with students from the secondary education stage, formalizing the teaching and learning of good practices for the correct management and treatment of waste, thus constructing education for sustainable development.

It is becoming increasingly necessary to include environmental instruction (including generation and treatment of waste) in the educational legislation of each country. Its presence and importance must be according to our society needs, allowing technical and economic evolution with respect for the environment in mind.

For a quality and correct development of environmental concepts, we need a secondary education curriculum adapted to the level and needs of the student, and also tailored to the current demands in this field of our society. On the other hand, it is necessary to promote an excellent training of teachers in this area of study, from a cognitive, emotional and attitudinal point of view. This endorsement becomes necessary to contribute to environmental awareness of future generations, as the current teachers can influence their students and generate responsible, critical and sustainable attitudes that will affect the health of the Earth.

\section{ACKNOWLEDGEMENTS}

The authors would like to thank the Regional Government of Extremadura (Project IB16068 and Grant GR15009) and the Spanish State Research Agency (Project EDU2016-77007-R) for their financial support, partially funded by the European Regional Development Fund.

\section{REFERENCES}

Adomssent, M., Godemann, J., \& Michelsen, G. (2007). Transferability of approaches to sustainable development at universities as a challenge. International Journal of Sustainability in Higher Education, 8(4), 385-402.

Aznar, P., Martínez-Agut, M. P., Palacios, B., Piñero, A., \& Ull, M. A. (2011). Introducing sustainability into university curricula: an analysis of teachers' preconceptions at University of Valencia. Environmental Education Research, 17(2), 145-166.

Barbier, E. (1987). The concept of sustainable economic development. Environmental Conservation, 14(2), 101-110.

Beatley, T., \& Manning, K. (1998). The ecology of place: Planning for environment, economy and community. Washington, DC: Island Press.

Berke, P. R., \& Conroy, M. M. (2000). Are we planning for sustainable development? An evaluation of 30 comprehensive plans. Journal of the American planning association, 66(1), 21-33.

Bray, C. (2008). Program evaluation of the sustainability of teaching methods. Environmental Education Research, 14(6), 655-666.

CONAMA (2010). Comisión Nacional del Medio Ambiente. Primer reporte sobre manejo de residuos sólidos [First report on solid waste management]. Chile: CONAMA.

Council Directive 91/156/EEC of 18 March 1991 amending Directive 75/442/EEC on waste.

De Vincentiis, G. (2012). La evolución del concepto de desarrollo sostenible [The evolution of the concept of sustainable development]. Medio Ambiente \& Derecho: Revista electrónica de derecho ambiental, 23.

Decreto 98/2016, de 5 de julio, por el que se establecen la ordenación y el currículo de la Educación Secundaria Obligatoria y del Bachillerato para la Comunidad Autónoma de Extremadura [Decree 98/2016, of July 5, establishing the management and curriculum of Compulsory Secondary Education and Baccalaureate for the Autonomous Community of Extremadura].

Firth, R., \& Winter, C. (2007). Constructing education for sustainable development: The secondary school geography curriculum and initial teacher training. Environmental Education Research, 13(5), 599-619.

Foladori, G., \& Tommasino, H. (2000). El concepto de desarrollo sustentable treinta años después [The concept of sustainable development thirty years later]. Desenvolvimento e Meio Ambiente, 1.

Gestión y Explotación de Servicios Públicos Extremeños [Management and Exploitation of Public Services of Extremadura] Retrieved from http://www.gespesa.es/index.php?modulo=contenido\&pagina=datos\&id_bloque=12\&id_area=3 
Gomera Martínez, A. (2008). La conciencia ambiental como herramienta para la Educación Ambiental. Conclusiones y reflexiones de un estudio en el ámbito universitario [Environmental awareness as a tool for Environmental Education. Conclusions and reflections of a university study]. Carpeta informativa del CENEAM. Firma del mes Noviembre 2008, 7-14.

Grace, M., \& Sharp, J. (2000) Exploring the actual and potential rhetoric-reality gaps in environmental education and their implications for pre-service teacher training, Environmental Education Research, 6(4), 331-345

Harborth, Hans-Jurgen. 1991. The debate about sustainable development: starting point for an environmentoriented international development policy? Economics, 44, 7-31.

Jóhannesson, I. Á., Norðdahl, K., Óskarsdóttir, G., Pálsdóttir, A., \& Pétursdóttir, B. (2011). Curriculum analysis and education for sustainable development in Iceland. Environmental Education Research, 17(3), 375-391.

Kibert, N. C. (2000). An analysis of the correlations between attitude, behavior andknowledge components of environmental literacy in undergraduate university students. Florida: University of Florida.

Lelé, S. M. (1991) Sustainable Development: a critical review. World Development, 19(6), 607-621.

Ley 10/1998 de 21 de abril. Ley de residuos [Law 10/1998 of 21 April. Waste Act].

Ley 22/2011 de 28 de julio. Ley de residuos y suelos contaminados [Law 22/2011 of July 28. Law on waste and contaminated soils].

Middleton, N., \& Keefe, P. O. (2001). Redefining Sustainable Development. London: Pluto Press.

Novo, M. (2009). La educación ambiental, una genuina educación para el desarrollo sostenible Environmental Education, a genuine education for sustainable development. Revista de Educación, 195-217.

OECD. Publishing. (2008). OECD environmental outlook to 2030. Organisation for Economic Co-operation and Development.

Pavlova, M. (2013). Teaching and learning for sustainable development: ESD research in technology education. International Journal of Technology and Design Education, 23(3), 733-748.

Pezzoli, K. (1997). Sustainable Development: a transdisciplinary overview of the literature. Journal of Environmental Planning and Management, 40(5), 549-574.

Real Decreto 1105/2014, de 26 de diciembre, por el que se establece el currículo básico de la Educación Secundaria Obligatoria y del Bachillerato [Royal Decree 1105/2014, of December 26, establishing the basic curriculum of Compulsory Secondary Education and Baccalaureate].

Resolución de 20 de enero de 2009, de la Secretaría de Estado de Cambio Climático, por la que se publica el Acuerdo del Consejo de Ministros por el que se aprueba el Plan Nacional Integrado de Residuos para el período 20082015 [Resolution of January 20, 2009, of the Secretary of State for Climate Change, which makes know the Agreement of the Council of Ministers approving the Integrated National Waste Plan for 2008-2015].

Scott, W. (2005) ESD: what sort of decade? What sort of learning? Key note address at the UK launch of the Unesco Decade for ESD December 13, 2005.

Summers, M., \& Kruger, C. (2003) Teaching sustainable development in primary schools: theory into practice. The Curriculum Journal, 14(2), 157-180.

Sureda-Negre, J., Catalán-Fernández, A., Álvarez-García, O., \& Comas-Forgas, R. (2013). El concepto de “desarrollo sostenible" en la regulación del currículum de la Educación Secundaria Obligatoria en España [The concept of "sustainable development" in the regulation of the curriculum of Compulsory Secondary Education in Spain]. Estudios pedagógicos (Valdivia), 39(1), 253-267.

Tilbury, D. (2011). Education for sustainable development: An expert review of processes and learning. Paris, France: UNESCO.

Tugurian, L. P., \& Carrier, S. J. (2017). Children's environmental identity and the elementary science classroom. The Journal of Environmental Education, 48(3), 143-153.

UNESCO (United Nations Educational, Scientific and Cultural Organization) (2005). United Nations decade of education for sustainable development (2005-2014): International implementation scheme (ED/DESD/2005/PI/01). Paris: UNESCO.

Vitousek, P., Mooney, H., Lubchenco, J., \& Melillo, J. (1997). Human domination of Earth's ecosystems. Science, 222, 494-499. 
WCED (World Commision on Environment and Development) (1987). Our Common Future. Oxford: Oxford University Press.

Williams, S., McEwen, L. J., \& Quinn, N. (2017). As the climate changes: Intergenerational action-based learning in relation to flood education. The Journal of Environmental Education, 48(3), 154-171.

http://www.ejmste.com 